\title{
Extracellular Serine-proteinases Isolated from Streptomyces alboniger: Partial Characterization and Effect of Aprotinin on Cellular Structure
}

\author{
Andréa Lopes, Rosalie RR Coelho, Maria Nazareth L Meirelles*, Marta Helena \\ Branquinha, Alane Beatriz Vermelho/ ${ }^{+}$
}

Departamento de Microbiologia Geral, Instituto de Microbiologia Professor Paulo de Góes, Universidade Federal do Rio de Janeiro, CCS, B1 I, 21949-900 Rio de Janeiro, RJ, Brasil *Laboratório de Ultraestrutura Celular, Departamento de Ultra-estrutura e Biologia Celular, Instituto Oswaldo Cruz, Av. Brasil 4365, 21045-900 Rio de Janeiro, RJ, Brasil

Streptomyces alboniger ATCC 12461 grown in brain heart infusion (BHI) medium produced two extracellular serine-proteinases, denoted SP I and SP II, which were purified by ammonium sulfate precipitation and aprotinin-agarose affinity chromatography. SP I was purified 88,9-fold and SP II 66,7-fold, with $33.4 \%$ and $10.4 \%$ yield, respectively. The optimum $\mathrm{pH}$ for the proteinases activity, using $\alpha$ - $N$-p-tosyl-L-arginine-methyl ester (TAME) as substrate, was 9-10 and the optimum temperature was $37^{\circ} \mathrm{C}$. The proteolytic activity of SP I and SP II was inhibited by aprotinin and SP I was partially inhibited by leupeptin, both serine-proteinase inhibitors. S. alboniger growth in BHI-liquid medium decreased when $5 \mu \mathrm{g} / \mathrm{ml}, 10 \mu \mathrm{g} / \mathrm{ml}$ of aprotinin was used, being completely inhibited with $20 \mu \mathrm{g} / \mathrm{ml}$ and $40 \mu \mathrm{g} / \mathrm{ml}$. At the ultrastructural level, aprotinin-treated S. alboniger cells showed swelling of the bacterial body and condensation of the genetic material, probably related to the inhibition of its growth.

Key words: Streptomyces alboniger - serine-proteinases - growth - aprotinin

Streptomycetes are Gram-positive bacteria with an unusual morphological complexity, including the sequential production of substrate and aerial mycelia and spores (Chater \& Hopwood 1984). This group of bacteria is industrially important because they produce several antibiotics, exoenzymes, such as proteinases, and other secondary metabolites of commercial value (Berdy 1984, Peczynska-Czoch \& Mordask 1988, Sanglier et al. 1993).

Several proteinases have been obtained from streptomycetes and biochemically characterized, such as Streptomyces pactum serine-proteinase, Streptomyces exfoliatus metallo- and serine-proteinases and Streptomyces rimosus aminopeptidase (Bockle et al. 1995, Kim \& Lee 1995, Vitale et al.

Research supported by the Conselho Nacional de Desenvolvimento Científico e Tecnolológico (CNPq), Financiadora de Estudos e Projetos (Finep-BID), Fundação Universitária José Bonifácio (FUJB), Fundação Oswaldo Cruz (Fiocruz), Conselho de Ensino para Graduados e Pesquisas (CEPG/UFRJ) and Fundação de Amparo à Pesquisa do Estado do Rio de Janeiro (Faperj). ${ }^{+}$Corresponding author. Fax: +55-21-560.8334. E-mail: immgbia@microbio.ufrj.br

Received 2 April 1998

Accepted 11 August 1999
1996). These enzymes are involved in the assimilation of proteinaceous nitrogen sources, degradation of aerial mycelium and sporulation processes, as well as in antibiotic production (Ginther 1979, Kitadokoro et al. 1994, Kang et al. 1995, Kim \& Lee 1996).

In the present study, we performed a qualitative analysis in SDS-PAGE-gelatin of proteinases produced by $S$. alboniger. Additionally, two serineproteinases were purified and partially characterized. The effects of aprotinin, a serine-proteinase inhibitor, on S. alboniger growth and upon the ultrastructure of this microorganism were also analyzed.

\section{MATERIALS AND METHODS}

Microorganism and growth conditions - $S$. alboniger ATCC 12461 was maintained on brain heart infusion (BHI) containing 1.5\% (w/v) agar. Liquid cultures were obtained by inoculating $30 \mathrm{ml}$ BHI medium with a suspension of approximately $10^{5}$ spores. This culture was used to inoculate 11 of BHI. The microorganism was grown for 14 days at $28^{\circ} \mathrm{C}$.

Obtention of cellular extract $(C)$ and extracellular concentrate $(E)$ - The cell-free culture supernatant (E) was obtained by centrifugation at $10,000 \mathrm{~g}$ for $15 \mathrm{~min}$ at $4^{\circ} \mathrm{C}$ and concentrated against polyethyleneglycol 4,000 for $24 \mathrm{hr}$ at $4^{\circ} \mathrm{C}$. E was 
mixed with SDS-PAGE sample buffer (125 mM Tris, pH 6.8, 4\% SDS, $20 \%$ glycerol and 2\% bromophenol blue) in a proportion of 7:3 (v/v). Cells were washed three times with isotonic buffer saline solution $(0.85 \%$ $\mathrm{NaCl}$ ) and ressuspended in $100 \mathrm{ml}$ of sample buffer in order to obtain the $\mathrm{C}$.

SDS polyacrylamide gels containing co-polymerized gelatin - Proteinases in $\mathrm{C}$ and $\mathrm{E}$ were assayed and characterized by electrophoresis in $7.5 \%$ SDS-PAGE (Laemmli 1970) with $0.1 \%$ copolymerized gelatin (Heussen \& Dowdle 1980). After running, the gels were soaked for $1 \mathrm{hr}$ at $25^{\circ} \mathrm{C}$ in $2.5 \%$ Triton X-100 solution, and incubated overnight at $37^{\circ} \mathrm{C}$ under two different conditions: $50 \mathrm{mM}$ phosphate buffer, $\mathrm{pH} 5.5$, and $100 \mathrm{mM}$ glycine- $\mathrm{NaOH}$ buffer, $\mathrm{pH}$ 10.0. Proteolytic activity was detected by staining gels for $1 \mathrm{hr}$ with $0.1 \%$ amido black in methanol-acetic-acid-water (30:10:60, v/v/v) and destaining in the same solvent. For enzymatic secretion studies, aliquots of $30 \mathrm{ml}$ from culture medium were daily collected during 14 days, concentrated and analyzed in 7.5\% SDS-PAGE gelatin using $50 \mathrm{mM}$ glycine- $\mathrm{NaOH}$ buffer, $\mathrm{pH} 10.0$.

Proteinases purification - The S. alboniger cellfree culture supernatant was used as the starting material for the purification of extracellular proteinases. (1) Ammonium sulfate precipitation - The culture supernatant was brought to $40 \%$ saturation with ammonium sulfate, followed by centrifugation at $10,000 \mathrm{~g}$ for $30 \mathrm{~min}$. The precipitated fraction was dissolved and dialysed against distilled water. After dialysis the fraction was centrifuged at $10,000 \mathrm{~g}$ for 45 min at $4^{\circ} \mathrm{C}$. (2) Affinity chromatography - The active fraction obtained from the ammonium sulfate fractionation was applied to an aprotinin-agarose column (Sigma), pre-equilibrated with $0.01 \mathrm{M}$ Tris$\mathrm{HCl}$ buffer, $\mathrm{pH} 5.0$, containing $5 \mathrm{mM} \mathrm{CaCl}_{2}$. After exhaustive washing in equilibrating buffer, the adsorbed proteins were eluted with the same buffer in a linear gradient of $\mathrm{CaCl}_{2}(5 \mathrm{mM}-15 \mathrm{mM})$. Fractions of $1 \mathrm{ml}$ were collected and the protein content detected at $280 \mathrm{~nm}$. Protein-containing fractions were pooled and used for further studies.

Protein concentration determination - Protein concentration was determined using bovine serum albumin as standard (Lowry et al. 1951).

Assay of proteinase - Activity of the extracellular proteinase was performed at $37^{\circ} \mathrm{C}$ by measuring the tosyl derivative released from $\alpha-\mathrm{N}$-p-tosyl-Larginine-methyl ester (TAME). The assay mixture $(1 \mathrm{ml})$ consisted: $800 \mu \mathrm{l} 0.2 \mathrm{M}$ glycine-NaOH buffer and $100 \mu \mathrm{l} 10 \mathrm{mM}$ substrate (TAME). The reaction was initiated by addition of $100 \mu \mathrm{l}$ of enzyme solution and incubated for $30 \mathrm{~min}$. Enzyme activity was determined at $247 \mathrm{~nm}$ (Aguiar et al. 1996). Assays were run in triplicate with simultaneous controls (substrate only). One unit of proteolytic activity was defined as the amount of enzyme required to produce an increase of 0.001 absorbance at $247 \mathrm{~nm}$ unit under standard assay conditions.

Optima pH and temperature - The effect of $\mathrm{pH}$ on enzymatic activity was determined under the standard assay conditions described above, using the following buffers: $0.1 \mathrm{M}$ citrate ( $\mathrm{pH}$ 4.0-5.0), 0.2 $\mathrm{M}$ sodium phosphate (6.0-8.0), $0.2 \mathrm{M}$ glycine- $\mathrm{NaOH}$ (9.0-10.0) and 0.1 M glycine- $\mathrm{NaOH}$ (11.0-12.8). The optimum temperature for enzyme activity $\left(28^{\circ} \mathrm{C}\right.$, $40^{\circ} \mathrm{C}, 50^{\circ} \mathrm{C}$ and $60^{\circ} \mathrm{C}$ ) was also determined, using $0.2 \mathrm{M}$ glycine- $\mathrm{NaOH}, \mathrm{pH} 10.0$ as buffer.

Effect of proteolytic inhibitors - For inhibition studies, the enzymes and inhibitors transepoxysuccinyl-L-leucylamido- (4-guanidino) butane (E-64), ethyleneglycol-bis ( $\beta$-aminoethyl ether) $\mathrm{N}, \mathrm{N}$, N', N'-tetraacetic acid (EGTA), ethyl-enediaminetetraacetic acid (EDTA), 1.10 phenantroline, phenylmethylsulfonyl fluoride (PMSF), soybean trypsin inhibitor (STI), aprotinin, leupeptin, tosyl-Lphenylalanylchloromethylketone (TPCK) and pepstatin were pre-incubated for $30 \mathrm{~min}$ prior to addition of the substrate (TAME). Assays were run in triplicate with simultaneous controls.

Effect of aprotinin on Streptomyces alboniger growth - The effect of aprotinin was observed using solid and liquid media. Briefly, $37 \mathrm{~g}$ of BHI was dissolved in 11 of distilled water. In solid media, agar was added at the concentration of $1.5 \%$. Twenty $\mathrm{ml}$ of culture medium was then poored per plate and allowed to harden. Different quantities of each amount of aprotinin $(25 \mu \mathrm{g}, 50 \mu \mathrm{g}, 100 \mu \mathrm{g}$ and 200 $\mu \mathrm{g}$ ) were added to a $20 \mu \mathrm{l}$ spore suspension (about $10^{3}$ ). This mixture was then inoculated on BHI agar plates and BHI-liquid medium. Aprotinin in BHIliquid medium was diluted to a final concentration of $5 \mu \mathrm{g} / \mathrm{ml}, 10 \mu \mathrm{g} / \mathrm{ml}, 20 \mu \mathrm{g} / \mathrm{ml}$ and $40 \mu \mathrm{g} / \mathrm{ml}$. The media were incubated at $28^{\circ} \mathrm{C}$ during seven days.

Ultrastructural analysis of aprotinin treated cells - Effects of aprotinin on S. alboniger growth on liquid media were determined by transmission electron microscopy. Cells were fixed for $1 \mathrm{hr}$ at $4^{\circ} \mathrm{C}$ with glutaraldehyde (GA) in $0.1 \mathrm{M}$ sodium cacodylate buffer, $\mathrm{pH} 7.2$ and subsequentely for $1 \mathrm{hr}$ at $4^{\circ} \mathrm{C}$ with $1 \% \mathrm{OsO}_{4}$. The cells were then dehydrated through an ascending series of acetone and embedded in Epon. Thin sections were picked up on 300 mesh copper grids and stained with uranyl acetate and lead citrate. The material was examined in a Zeiss EM 10B transmission electron microscopy.

\section{RESULTS}

SDS-PAGE-gelatin - The proteinases in $\mathrm{E}$ and $\mathrm{C}$ extracts were most active at $\mathrm{pH} 10.0$ (Fig. 1A). Proteinases migrating at $200 \mathrm{kDa}, 45 \mathrm{kDa}$ and $35 \mathrm{kDa}$ were detected in both extracts. The extracellular proteinase profile showed additional bands migrat- 


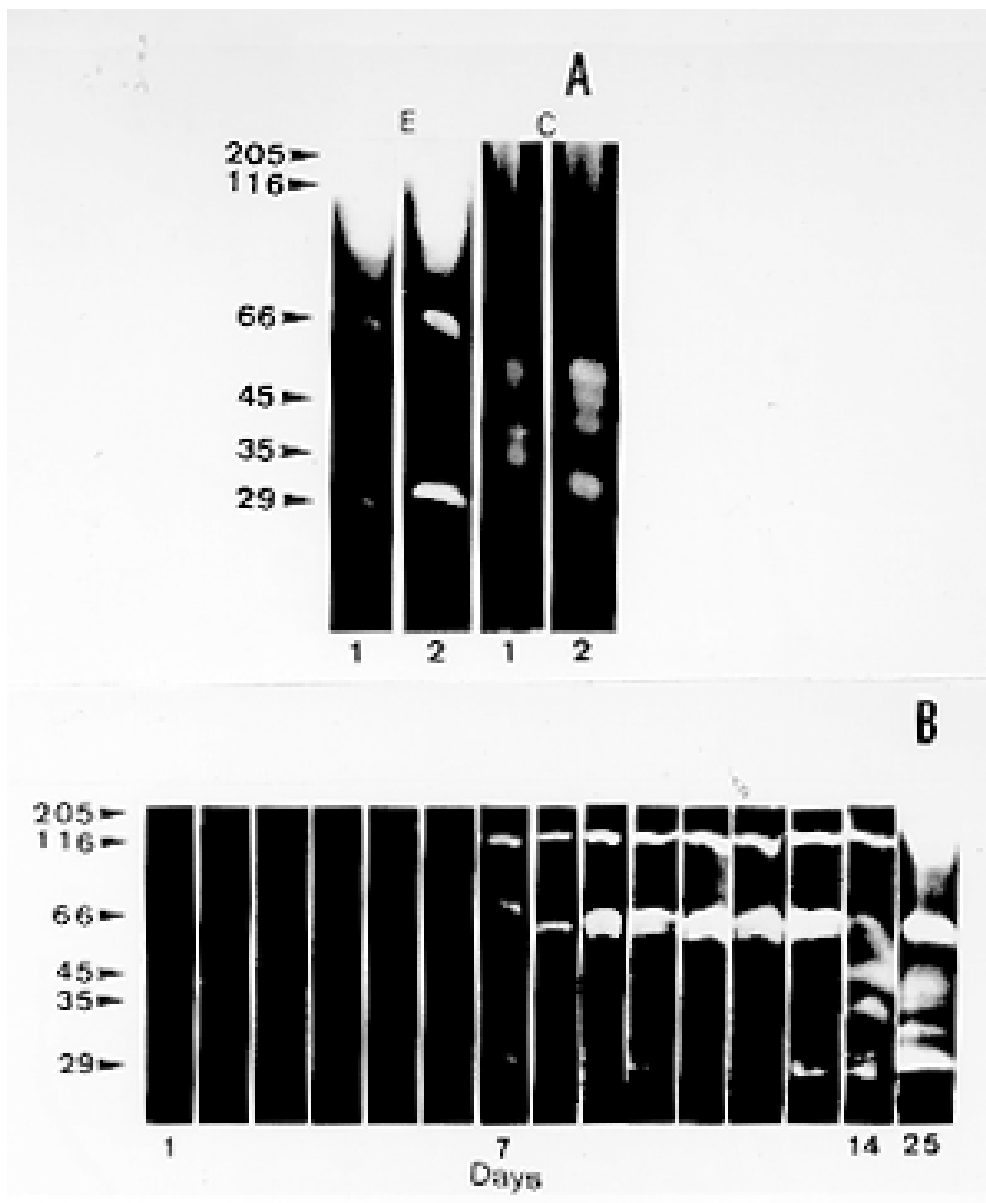

Fig. 1: SDS-PAGE-gelatin analysis of Streptomyces alboniger proteinases. A: cellular (C) and extracellular (E) proteinases. 1: $\mathrm{pH} 5.5$ and 2: pH 10.0; B: E proteinases secretion profile until the 25th day. Molecular weight markers in $\mathrm{kDa}$ are indicated in the left side of the figure.

ing at $66 \mathrm{kDa}$ and $29 \mathrm{kDa}$ while proteinases with 55 $\mathrm{kDa}, 50 \mathrm{kDa}$ and $20 \mathrm{kDa}$ were observed only in cellular extracts. Secretion studies revealed that during the first seven days of culture, only the $200 \mathrm{kDa}$ and $66 \mathrm{kDa}$ proteinases were secreted to culture medium (Fig. 1B). After seven days, the $29 \mathrm{kDa}$ enzyme was also detected. No qualitative difference was observed until the 13th day. Additional bands migrating at $35 \mathrm{kDa}$ and $45 \mathrm{kDa}$ were found in the 14th day. This profile was observed until the 25th day of cultive.

Proteinase purification - Fig. 2 shows the elution profile of $S$. alboniger extracellular proteinases using an aprotinin-agarose affinity column chromatography. Two peaks of serine proteinases (SP I and SP II) eluted with $8-10 \mathrm{mM} \mathrm{CaCl}_{2}$ were obtained. Fractions 2-6 (corresponding to SP I) and 7-12 (corresponding to SP II) were collected and pooled due to protein content and proteolytic activity. The final enzyme preparations showed single protein and protease bands on SDS-PAGE and SDS-
PAGE - gelatin (Fig. 3). This analysis demonstrated that SP I and SP II molecular masses are aproximately $29 \mathrm{kDa}$ and $66 \mathrm{kDa}$, respectively. The remaining E proteolytic activity was not retained by the affinity column. The purification procedure is summarized in Table I. The SP I was purified 88.9 fold with a yield of $33.4 \%$ and the SP II was purified 66.7 fold with a yield of $10.4 \%$.

Optima pH and temperature - The optimum $\mathrm{pH}$ for SP I and SP II activities was 9-10, with a markedly reduction in activity at $\mathrm{pH}$ values above $\mathrm{pH} 11.0$ (Fig. 4). The optimum temperature for SP I and SP II activities was $37^{\circ} \mathrm{C}$. At $28^{\circ} \mathrm{C}$ weak enzymatic activity was observed with both proteinases. SP I and SP II were inactivated when incubated at $60^{\circ} \mathrm{C}$ (Fig. 5).

Effects of proteolytic inhibitors - The effects of several inhibitors on SP I and SP II activities are shown in Table II. The activity of SP I and SP II were significantly inhibited by aprotinin and SP I was partially inhibited by leupeptin, both serineproteinase inhibitors. 


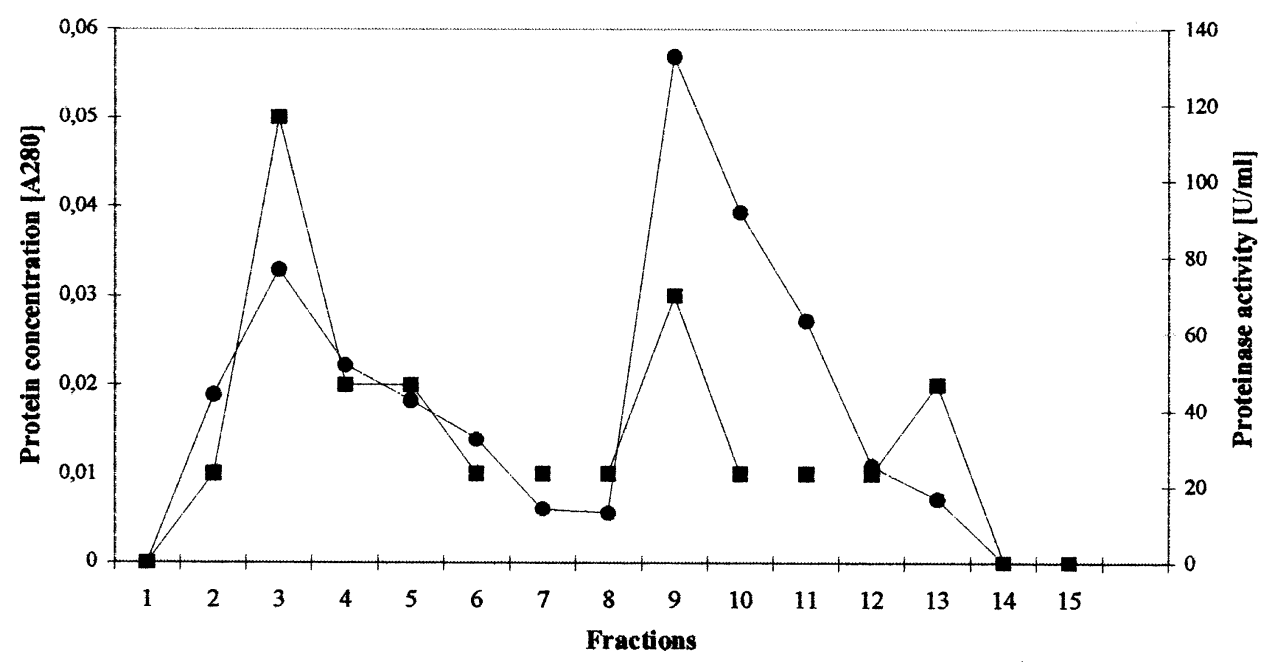

Fig. 2: elution profile of Streptomyces alboniger extracellular proteinases using aprotinin-agarose affinity chromatography (•) protein concentration and $(\bullet)$ proteinase activity. Fractions of $1 \mathrm{ml}$ were collected.

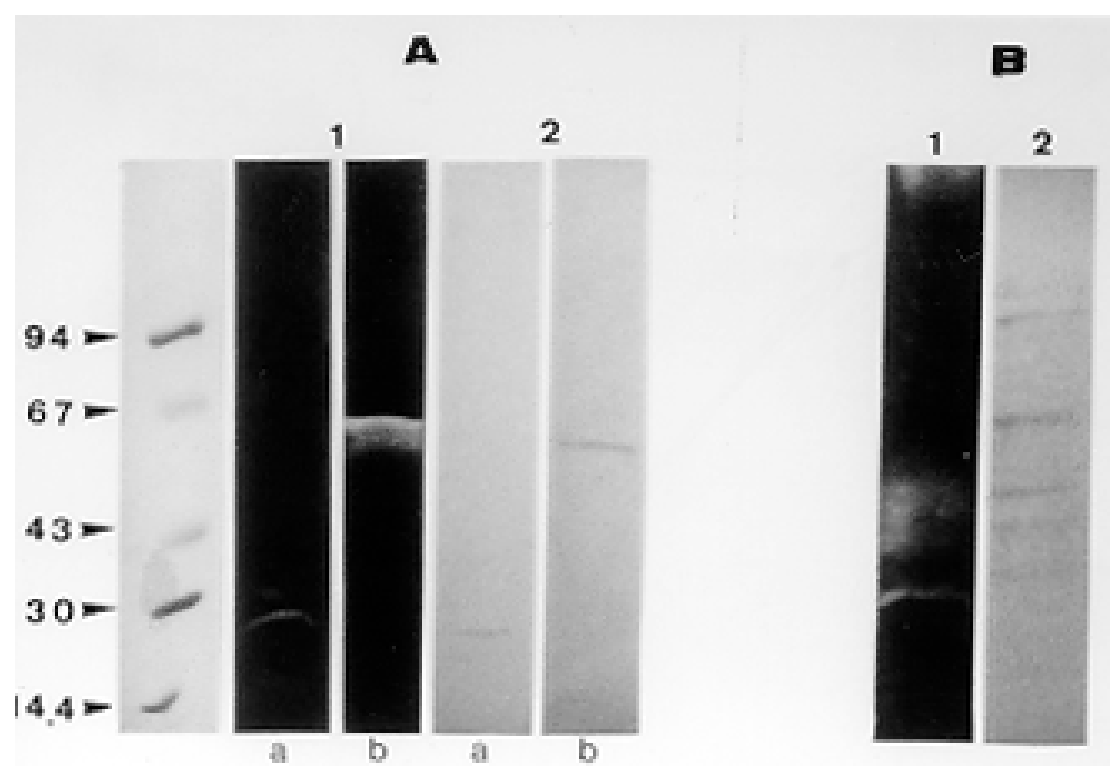

Fig. 3 - A: SDS-PAGE-gelatin (1) and SDS-PAGE (2) analyses of affinity-purified Streptomyces alboniger extracellular proteinases SP I (a) and SP II (b); B: extracellular proteases (1) and proteins (2) not adsorbed in the aprotinin-agarose column.

TABLE I

Purification of Streptomyces alboniger extracellular proteinases

\begin{tabular}{lcccccc}
\hline \multicolumn{1}{c}{ Fractions } & $\begin{array}{c}\text { Volume } \\
(\mathrm{ml})\end{array}$ & $\begin{array}{c}\text { Total protein } \\
(\mathrm{mg})\end{array}$ & $\begin{array}{c}\text { Total } \\
\text { activity }(\mathrm{U})\end{array}$ & $\begin{array}{c}\text { Specific activity } \\
\left(\mathrm{U} \mathrm{mg} \mathrm{ptn}^{-1}\right)\end{array}$ & $\begin{array}{c}\text { Purification } \\
(-\mathrm{fold})\end{array}$ & $\begin{array}{c}\text { Yield } \\
(\%)\end{array}$ \\
\hline $\begin{array}{l}\text { Culture medium } \\
\begin{array}{l}\text { Ammonium sulfate } \\
\text { precipitation }\end{array}\end{array}$ & 300 & 320.8 & 479.6 & 1.5 & 1 & 100 \\
$\begin{array}{l}\text { Aprotinin-agarose } \\
\text { SP I }\end{array}$ & 15 & 25.74 & 229.3 & 8.9 & 5.9 & 47.8 \\
SP II & 4 & 1.2 & 160 & 133.3 & 88.9 & 33.4 \\
\hline
\end{tabular}




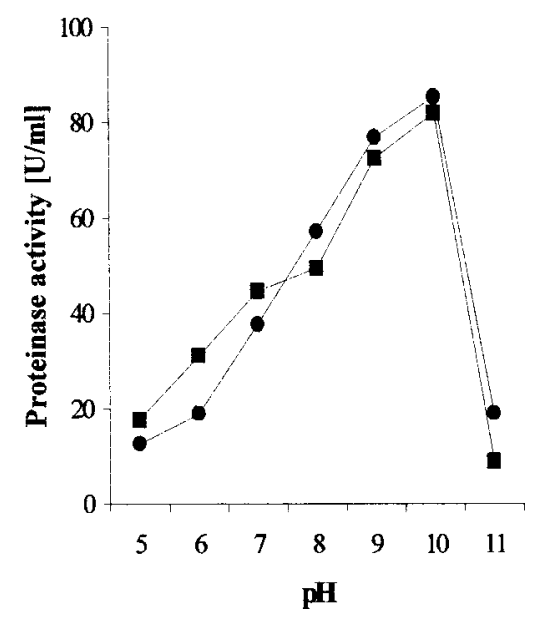

Fig. 4: effect of $\mathrm{pH}$ for SP I and SP II proteolytic activity (- ) SP I and (•) SP II.

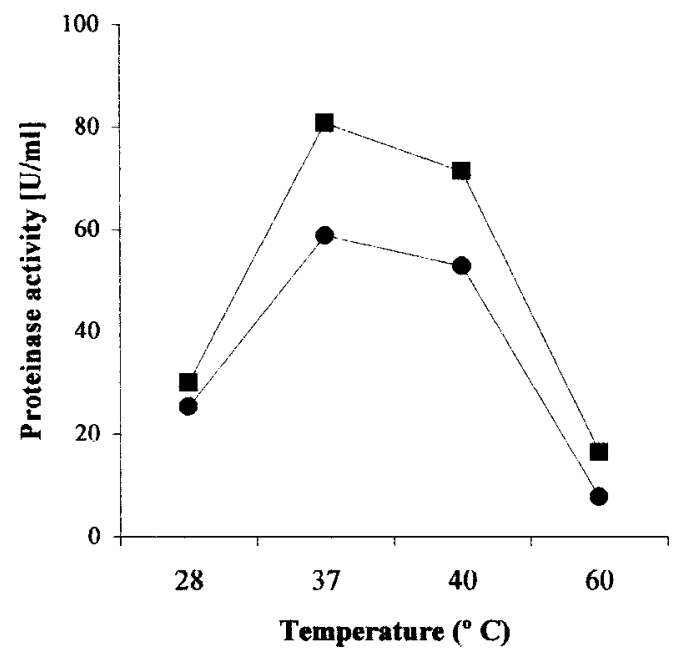

Fig 5: effect of temperature for SP I and SP II proteolytic ativity ( $\bullet$ ) SP I and $(\bullet$ ) SP II.

Effect of aprotinin on S. alboniger growth - S. alboniger cells were completely inhibited by addition of the aprotinin inhibitor to BHI-agar in all concentrations used (data not shown). The effect of addition of aprotinin on S. alboniger growth in BHIliquid medium was analyzed at the ultrastructural level. When $40 \mu \mathrm{g}$ and $20 \mu \mathrm{g} / \mathrm{ml}$ aprotinin was added, complete inhibition was achieved during the seven days of growth. At concentrations of $5 \mu \mathrm{g} / \mathrm{ml}$ and $10 \mu \mathrm{g} / \mathrm{ml}$, of the proteolytic inhibitor a significant decrease in growth was observed.

Ultrastructural analysis - The concentrations of $5 \mu \mathrm{g} / \mathrm{ml}$ and $10 \mu \mathrm{g} / \mathrm{ml}$ were used in ultrastructural analysis and the same effects were observed. Aprotinin treatment of $S$. alboniger caused a swelling of the bacterial body. Fig. 6B shows the septum and the cell envelope thicker than control cells (Fig.
TABLE II

Effect of various proteolytic inhibitors on Streptomyces alboniger SP I and SP II activity measured using TAME as substrate. The results are the mean of three experiments

\begin{tabular}{|c|c|c|c|}
\hline \multirow[t]{2}{*}{ Inhibitor } & \multirow[t]{2}{*}{ Concentration } & \multicolumn{2}{|c|}{$\begin{array}{l}\text { Residual } \\
\text { activity (\%) }\end{array}$} \\
\hline & & SP I & SP II \\
\hline - & - & 100 & 100 \\
\hline PMSF & $2 \mathrm{mM}$ & 98 & 99 \\
\hline STI & $100 \mu \mathrm{g} / \mathrm{ml}$ & 68 & 81 \\
\hline Aprotinin & $100 \mu \mathrm{g} / \mathrm{ml}$ & 28 & 30 \\
\hline TPCK & $100 \mu \mathrm{l}$ & 83 & 70 \\
\hline Leupeptin & $100 \mu \mathrm{M}$ & 43 & 88 \\
\hline E-64 & $20 \mu \mathrm{M}$ & 73 & 72 \\
\hline EGTA & $1 \mathrm{mM}$ & 81 & 72 \\
\hline EDTA & $1 \mathrm{mM}$ & 97 & 79 \\
\hline 1,10 phenantroline & $50 \mu \mathrm{M}$ & 71 & 73 \\
\hline Pepstatin & $2 \mu \mathrm{M}$ & 97 & 90 \\
\hline
\end{tabular}

6A). A low electron density in these structures was also observed after aprotinin treatment. However, the major alteration caused by aprotinin was a condensation of the genetic material (Fig. 6B).

\section{DISCUSSION}

This work describes the purification and some biochemical properties of two extracellular proteinases isolated from $S$. alboniger. In this genus the extracellular serine-proteinases are expressed in the stationary phase and regulate the morphogenesis process closely linked to mycelial growth (Kim \& Lee 1995). These enzymes were purified using aprotinin affinity chromatography. Studies with inhibitors suggest that both enzymes were serineproteinases because they were inhibited by aprotinin. SP I was inhibited by leupeptin and partially inhibited by STI, which are used to trypsinlike proteinases. Interestingly, the proteinases SP I and SP II were insensitive to PMSF, as previously observed for an extracellular serine-proteinase isolated from Streptomyces sp. (Bono et al. 1996). This finding was consistent with the possibility that they could be trypsin-like proteinases since PMSF reacts very slowly with trypsins (Powers \& Haper 1986). At the present moment all serine-proteinases found in Streptomyces spp. are chymotrypsin-, trypsin- and subtilisin-like enzymes (Sidhu et al. 1994). The optima $\mathrm{pH}$ and temperature values determined for these enzymes are in agreement with previous reports that described neutral to alkaline values of $\mathrm{pH}$ and temperatures ranging from $35^{\circ} \mathrm{C}$ to $75^{\circ} \mathrm{C}$ for proteinases purified from streptomycetes (Chandrasekaran \& Dhar 1987, Kang et al. 1995, Kim \& Lee 1996, Yeoman \& Edwards 1997). 


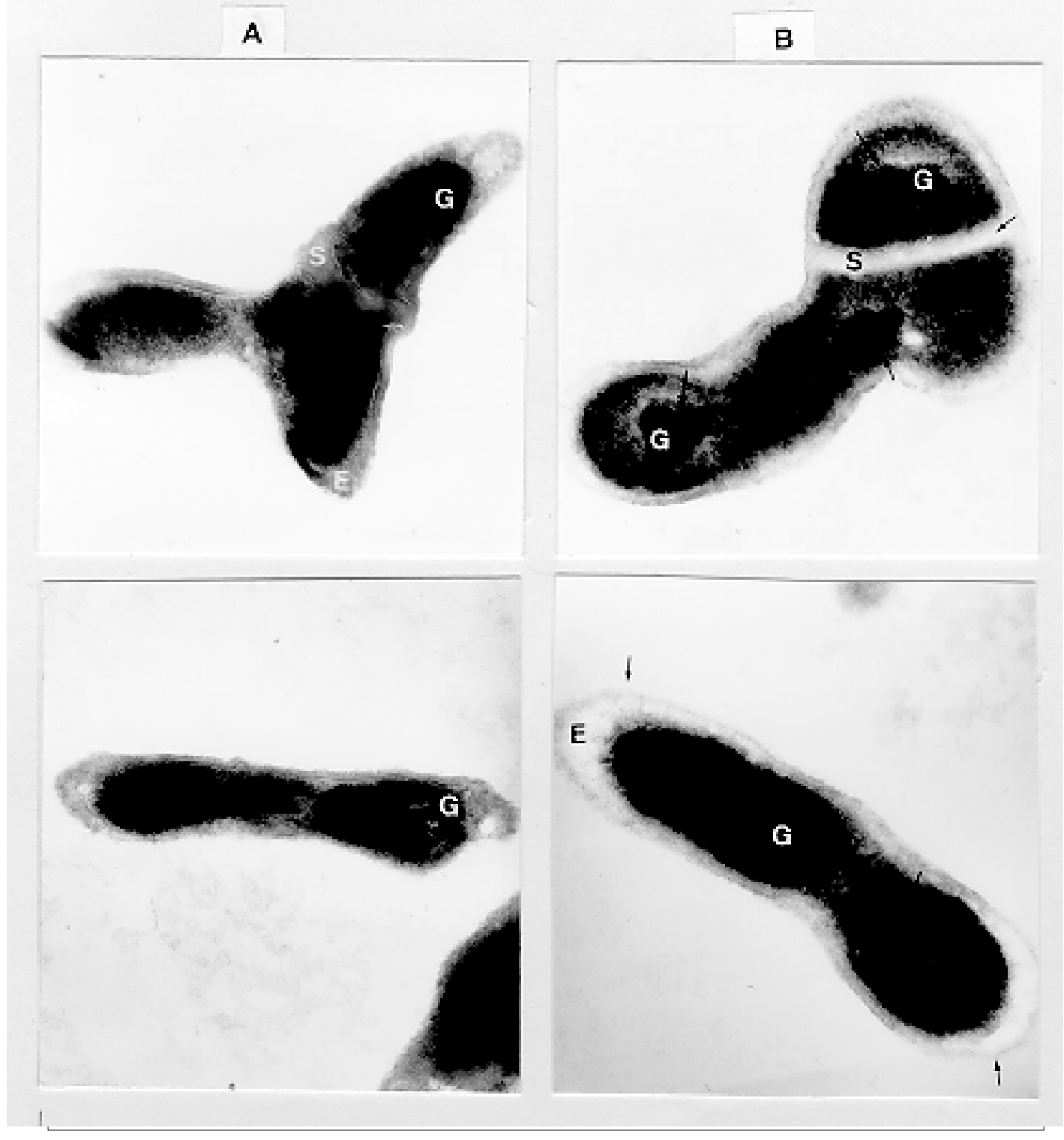

Fig 6: ultrastructural analysis of aprotinin-treated Streptomyces alboniger cells. A: control cells; B: aprotinin-treated cells. E: cellular envelope; S: septum; G: genetic material. Arrows indicate the major alterations detected in S. alboniger cells induced by aprotinin. For more details, see results.

When S. alboniger was grown in the presence of aprotinin its growth was partially or completely inhibited depending on the inhibitor concentration. Ultrastructural analysis showed a low electron density of the cell wall and of the septum as well as a little swelling of the bacterial body consistent with the observations of Pellegrini et al. (1992). The images exhibited centrally the genetic material, displaying a more condensed structure.

Proteolytic enzymes such as serine-proteinases may be important in the regulation of cell prolifera- tion (Berezney 1979). Several studies with eukaryotic cells have demonstrated mitogenic effects of proteinases and suppression of cellular proliferation due to proteinases inhibitors (Ku et al. 1981, Wong et al. 1987, Jensen \& O'Leary 1990). The coordination of cell cycle progression and cell differentiation with the initiation of DNA replication is fundamental, yet poorly understood in procaryotic cells. The participation of serine-proteinases in the DNA replication of Escherichia coli, S. aureus, $S$. epidermidis and Bacillus subtilis, has been de- 
scribed (Irisawa et al. 1993, Kato et al. 1994, Jiang et al. 1998). Jenal and Fuchs (1998) suggested that the ubiquitous occurrence of the serine-proteinases in various bacteria is linked to their pivotal role in the onset of DNA synthesis by the specific degradation of proteins responsible for the negative control of chromosome replication. With regard to the role played by proteases in DNA synthesis of eukaryotic cells, a number of mechanisms have been suggested. In particular one of them indicated that serine-proteinases may be involved in the conversion of chromatin into an acceptable DNA polymerase substrate, probably acting upon nuclear proteins involved in DNA folding (Jensen $\&$ O'Leary 1990). On the other hand, the $S$. alboniger DNA alterations detected after aprotinin treatment could be due to antibacterial activity of the inhibitor as shown previously (Pellegrini et al. 1992).

Our results point to a direct correlation between the action of aprotinin and the inhibition of $S$. alboniger growth. Additional studies will be required to elucidate the precise mechanisms behind this inhibition.

\section{REFERENCES}

Aguiar AS, Alves, CR Melgarejo A, Giovanni-De-Simone S 1996. Purification and partial characterization of a thrombin-like/gyroxin enzyme from bushmaster (Lachesis muta rhombeata) venom. Toxicon 34 : 555565.

Berdy J 1984. Recent developments of antibiotic research and classification of antibiotics according to chemical structure. Adv Appl Microbiol 18: 309-406.

Berezney R 1979. Effect of protease inhibitors on matrix proteins and the association of replicating DNA. Exp Cell Res 123: 411-414.

Böckle B, Galunsky B, Müller R 1995. Characterization of a keratinolytic serine proteinase from Streptomyces pactum DMS 40530. Appl Environmen Microbiol 61: 3705-3710.

Bono F, Savi P, Tuong A, Maftouh M, Pereillo J, Capdevielle J, Guillemot J, Maffrand J, Herbert J 1996. Purification and characterization of a novel protease from culture filtrates of a Streptomyces $\mathrm{sp}$. FEMS Microbiol Letters 141: 213-220.

Chandrasekaran S, Dhar SC 1987. Multiple proteases from Streptomyces moderatus. II. Physicochemical and enzymatic properties of the extracellular proteases. Arch Biochem Biophys 257: 402-408.

Chater KF, Hopwood DA 1984. Streptomyces genetics, p. 229-286. In M Goodfellow, M Mordask \& T Williams (eds), The Biology of Actinomycetes, Academic Press, London, UK.

Ginther CL 1979. Sporulation and the production of serine protease and cephamicin C by Streptomyces lactamdurans. Antimicrobial Agents Chemother 15: 522-526.

Heussen C, Dowdle EB 1980. Eletrophoretic analysis of plasminogen activators in polyacrylamide gels con- taining sodium dodecyl sulfate and copolymerized substrate. Analytical Biochem 102: 196-202.

Irisawa T, Kato M, Muramatu M 1993. Effects of various esters of trans-4-guanidinomethyl-cycloxanecarboxylic acid, trypsin inhibitors, on the growth of Bacillus subtilis. Biol Pharm Bull 16: 1211-1215.

Jenal U, Fuchs T 1998. Na essential protease involved in bacterial cell-cycle control. EMBO J 17: 56585669.

Jensen TL, O’Leary JJ 1990. DNA synthesis in isolated resting nuclei: Evidence for protease-dependent nonreplicative nucleotide incorporation. Exp Cell Res 190: 85-90.

Jiang X, Zhang M, Ding Y, Yao J, Chen H, Zhu D, Muramatu M 1998. Escherichia coli prlC gene encodes a trypsin-like proteinase regulating the cell cycle. J Biochem 124: 980-985.

Kang SG, Kim IS, Rho YT, Lee KJ 1995. Production dynamics of extracellular proteases accompanying morphological differentiation of Streptomyces albidoflavus SMF301. Microbiology 141: 3095-3103.

Kato M, Irisawa T, Muramatu M 1994. Antibacterial effects of esters of guanidino- and amidino-acids trypsin inhibitors. J Enzyme Inhibition 8:25-37.

Kim IS, Lee KJ 1995. Physiological roles of leupeptin and extracellular proteases in mycelium development of Streptomyces exofoliatus SMF 13. Microbiology 141: 1017-1025.

Kim IS, Lee KJ 1996. Trypsin-like protease of Streptomyces exofoliatus SMF13, a potential agent in mycelial differentiation. Microbiology 142: 1797-1806.

Kitadokoro K, Tsuzuki H, Nakamura E, Sato T, Teraoka H 1994. Purification, characterization, primary structure, crystallization and preliminary crystallographic study of a serine proteinase from Streptomyces fradiae ATCC 14544. Eur J Biochm 220: 55-61.

Ku GSB, Quigley JP, Sultzer BM 1981. Time-dependent inhibition of tuberculin-induced lymphocyte DNA synthesis by a serine protease inhibitor. $J$ Immunol 126: 2209-2214.

Laemmli VK 1970. Clevage of structural during the assembly of the head of bacteriophage T4. Nature 227: 680-685.

Lowry OH, Rosebrough NJ, Farr AL, Randall RJ 1951. Protein measurement with the Folin phenol reagent. J Biol Chem 193: 264-275.

Peczynska-Czoch W, Mordask M 1988. Actinomycete enzymes, p. 219-283. In M Goodefellow, ST Williams \& M Mordask (eds), Actinomycetes in Biotechnology, Academic Press, London.

Pellegrini A, Thomas RF, Wild P 1992. Bactericidal activities of lysozyme and aprotinin against Gramnegative and Gram-positive bacteria related to their basic character. J Appl Bacteriol 72: 180-187.

Powers JC, Harper JW 1986. Inhibitors of serine proteinases, p. 55-152. In AJ Barrett \& G Salveson (eds), Proteinases Inhibitors, Elsevier Science Publishers BV, Amsterdam.

Sanglier JJ, Haag H, Huck TA, Fehr T 1993. Novel compounds from actinomycetes: a short review. Res Microbiol 144: 633-642. 
Sidhu SS, Kalmar GB, Willis LG, Borgfords TJ 1994. Streptomyces griseus proteases C. Can J Biol Chem 269: 20167-20171.

Vitale J, Skrtié I, Abramié M 1996. An intracellular aminopeptidase from Streptomyces rimosus that prefers basic amino acids. Arch Microbiol 165: 409-414.

Wong RL, Gutowski JK, Katz M, Goldfarb RH, Cohen
S 1987. Induction of DNA synthesis in isolated nuclei by cytoplasmic factors: inhibition by protease inhibitors. Proc Natl Acad Sci 84: 241-245.

Yeoman KH, Edwards C 1997. Purification and characterization of the proteases enzymes of Streptomyces thermovulgaris grown in rapemeal-derived media. $J$ Appl Microbiol 82: 149-156. 